This is an electronic reprint of the original article. This reprint may differ from the original in pagination and typographic detail.

Author(s): Nikula, Tarja

Title: $\quad$ On the role of peer discussions in the learning of subject-specific language use in CLIL

Year: $\quad 2012$

Version:

Please cite the original version:

Nikula, T. (2012). On the role of peer discussions in the learning of subject-specific language use in CLIL. In E. A. Soler, \& M.-P. Safont-Jordà (Eds.), Discourse and language learning across L2 instructional settings (pp. 133-153). Rodopi. Utrecht Studies in Language and Communication, 24.

https://doi.org/10.1163/9789401208598_008

All material supplied via JYX is protected by copyright and other intellectual property rights, and duplication or sale of all or part of any of the repository collections is not permitted, except that material may be duplicated by you for your research use or educational purposes in electronic or print form. You must obtain permission for any other use. Electronic or print copies may not be offered, whether for sale or otherwise to anyone who is not an authorised user. 


\title{
On the role of peer discussions in the learning of subject-specific language use in $\mathrm{CLIL}^{1}$
}

\author{
Tarja Nikula \\ University of Jyväskylä
}

\section{Introduction}

Language learners' discourse, the theme of this volume, is approached in this chapter from the viewpoint of content and language integrated learning, known as CLIL (e.g. Coyle, Hood \& Marsh 2010). The context is Finland, with data from secondary level history classes taught in English. More specifically, this chapter explores learner discourse in a hitherto underexplored context: group-work situations where students are involved in peer discussions without the presence of the teacher. While reaching a research-based understanding of the dynamics of teacher-student interaction in CLIL settings continues to be important for the whole CLIL enterprise and a goal worth pursuing further, it is also worthwhile to direct an analytical gaze at group-work situations and at learners' joint processes of negotiation and interaction, because we know less about the value of these contexts for learning.

What further characterizes this chapter is that rather than focusing on how students learn or how well they master the target language as a system (i.e. paying attention to the correctness of formal aspects of language), the purpose is to explore what students' group-work interaction reveals about content and language integration, a crucial concern in CLIL given its dual and overlapping goals. In so doing, it seeks to investigate students' joint processes of meaning making and the extent to which their discursive practices reveal any orientation to subject-specific language use. The focus is thus on the very notion of subject and language integration, how students coconstruct understanding of a subject-specific activity, and the type of language this requires.

Theoretically, the study is based on a discourse-pragmatic orientation to interaction which emphasizes both the necessity of situated exploration of

\footnotetext{
${ }^{1}$ This study is a part of a research project 'Language and content integration: towards a conceptual framework', funded by the Academy of Finland (20112014).
} 
the details of talk and attention to the social-interpersonal dimensions inherent in any communicative encounter (for more details, see Nikula 2005, 2008). As regards the approach to learning, the study draws on socioconstructivist understandings of learning, according to which it is useful to see learning as social accomplishment and meaning making as a joint construction rather than a process undertaken solely by individuals (e.g. Lantolf \& Poehner 2008).

\section{Language and content integration}

Content and language integrated learning (CLIL) is an educational approach that aims at the simultaneous learning of language and subject; it has steadily gained ground in Europe especially since the 1990s (for overview, see Dalton-Puffer, Nikula \& Smit 2010b). Research on CLIL is also flourishing, and we now know a great deal both about the benefits of CLIL and about areas needing further development (e.g. Ruiz de Zarobe \& Jiménez Catalan 2009, Coyle, Hood \& Marsh 2010, Dalton-Puffer, Nikula \& Smit 2010a). Learning outcomes, especially as regards target language learning, have been extensively explored, and there is also a growing number of studies that have investigated various aspects of CLIL classroom discourse (e.g. contributions in Dalton-Puffer and Smit 2007).

Recently, researchers have also highlighted the need to conceptualize language learning and competence in CLIL in ways that take better into account the notion of integration, i.e. that the objective in CLIL is for learners to acquire subject-specific language in the target language rather than 'generic' foreign language knowledge. For example, Gajo (2007: 564) argues that in CLIL research today, "a firm basis of reflection on the very concept of integration is missing". Accordingly, Dalton-Puffer et al. (2010c: 288-289) suggest that the fusion of language and content deserves more research attention than has until now been the case; they suggest that tackling the question of integration to the full will probably also require a transdisciplinary research construct. In a similar vein, Coyle (2007: 548) argues for the need for "critical analysis and discourse of emergent CLIL theoretical principles at both macro and micro levels" that would account for the essence of CLIL, i.e. that it combines learning to use language and using language to learn.

Focusing on what language and content integration in essence means is important because it has implications for different levels of CLIL practice. 
For example, in terms of pedagogy, teachers need to consider how instruction can maximally support the successful learning of language and content. The same applies to CLIL materials development. In terms of assessment, there is plenty of scope for research to determine the intertwined nature of content and language and how to take this duality into account when evaluating student performance (cf. Coetzee-Lachmann 2007).

When writing about bilingual education, Leung (2005: 239) highlights the importance of "close-up knowledge" based on classroom research by arguing that "claims for or against bilingual education of any form ring hollow when there is not a clear sense of what happens inside the classroom". In this spirit, this chapter brings the question of content and language integration to the level of classroom discourse because it is at the concrete level of classroom activities and practices that integration is brought into being by teachers and students.

That language has an important role in learning any school subject is not a novel idea; it has been investigated extensively in earlier research. Lemke's (1990) book on the role of language in science education is a pioneering work that has influenced the thinking of many researchers. Researchers working within the systemic functional paradigm have been particularly active in exploring the language of school subjects and language use in classrooms (e.g. Christie 2002, Schleppegrell 2004, Coffin 2006). Mortimer and Scott (2003), for their part, adopt a socioculturally and dialogically oriented approach to investigate meaning making in secondary school science classrooms.

While the intertwined nature of language and content concerns all learners, the simultaneous challenge of learning them both is highlighted when instruction takes place through languages other than the learners' native language. Most of the research referred to above on subject-specific language use and learning has dealt with participants who are operating in classrooms in their L1. However, the popularity of immersion education and various forms of bilingual education (see e.g. Fortune \& Tedick 2008, García 2009) and the fact that classrooms all over the world today, especially in urban contexts, are becoming increasingly multilingual (Creese \& Martin 2003) make it necessary to consider the effects that operating in languages other than L1 has on learning subject-specific literacies. As regards CLIL, its rapid spread in Europe during the last couple of decades has directed researchers' attention to questions of subject-specific speaking and writing. For example, a relevant study from the perspective of this paper, which focuses on history classrooms, is the study by Llinares and Whittaker (2010 
which shows that learning the appropriate language of history in speaking and writing poses problems for both CLIL students and for those studying in their L1. Järvinen (2010) comes to similar conclusions when investigating Finnish lower secondary learners' written essays on historical subjects. Lim Falk's (2008) study on science classrooms shows that CLIL students taught through English used less relevant subject-based language in speech and writing than control students taught in Swedish. Other CLIL research specifically focusing on subject-specific competence includes CoetzeeLachmann's (2007) study on the assessment of subject-specific task performance in geography and Nikula's (2010) case study on the ways in which a biology teacher makes subject-specific language salient in his classroom talk when teaching biology in Finnish and, during CLIL lessons, in English.

Earlier research has thus made clear the importance of studying the realisations and implications of content and language integration. As pointed out above, this chapter addresses this question from the perspective of secondary level CLIL history classrooms, with particular attention to what students' peer discussions in group-work situations reveal about subjectspecific language use.

\section{Data and analytic approach}

The data for the paper derive from a larger set of CLIL classroom recordings made in secondary schools in Finland. The data under scrutiny here are from $7^{\text {th }}$ grade history lessons with a class of 14 students aged 13 . The students are part of a group which receives extensive CLIL, with all other subjects apart from Finnish being instructed through English. Most of the students have had all the six years of their elementary education from grades 1 to 6 in Finnish, with the exception of one boy who is a native speaker of English.

In the history lessons studied in this chapter, students are working in pairs or small groups, with the teacher (a native speaker of English) circling round the classroom, providing assistance when groups need it but otherwise leaving responsibility for the work to the learners. There are 4 groups altogether, each with a tape recorder on the table. However, this paper is based on audio recordings of only three groups because the contribution of one of the groups was unavailable due to technical problems in the recording. There are two 90-minute sessions from each of the groups, recorded on consecutive days, i.e. altogether 9 hours of recorded group-work data. 
The topics dealt with in the group-work sessions concern the Industrial Revolution and the American Civil War. More specifically, the class has been told by the teacher to discuss and work through the causes and consequences of the Industrial Revolution and the American Civil War, and through that discussion both to come to an overall understanding of 'the big picture' of these phenomena and to pick out the most important aspects of the two events, 'the nutshell', the issues presented concisely. Students have prepared for the group-work sessions partly during previous lessons, when their teacher has led them through the topic areas, partly through their homework. The materials they are using when working in the classroom include handouts and reference books in English, dictionaries, and history textbooks in Finnish, which they are using (as in most other CLIL subjects in the school) as support material to give them an idea of how the content area is handled in Finnish. They may have used the internet when doing their homework but computers are not available in the classroom.

The working language during the group work is English and students keep to it almost all the time; very little Finnish is used. This may be due to the teacher as well as one of the students in the class being native speakers of English. However, it is notable that even in groups where everyone has Finnish as their L1, the use of English prevails.

As pointed out above, the analysis aims at exploring instances where subjectspecific language becomes an issue, whether explicitly or implicitly. However, defining subject-specific language is not an easy task. Firstly, there are certain features of language use that belong to academic and educational contexts in general rather than being confined to particular subjects. According to Dalton-Puffer (2007:128), typical academic language functions include, for example, analysing, defining, explaining, hypothesising, narrating; even though such functions also exist in everyday talk, their high frequency and co-occurrence are typical of educational and academic contexts. Each school subject and disciplinary area also tends to have its own special terminology. History, the focus in this chapter, may not be as rich in special terminology as, say, biology or chemistry, but it does have its agreed-upon labels and phrases for given phenomena and periods in time (e.g. the Industrial Revolution in the present data). School subjects also differ from one another in terms of the discourse patterns through which knowledge gets constructed. Typical discourse patterns in history include narratives, causal explanations, recording, explaining and arguing (e.g. Schleppegrell, Achugar \& Oteíza 2004, Coffin 2006, Llinares \& Morton 2010). 
In this study, the analysis is informed by the points above in that the search for instances of talk that reflect students' awareness of subject-specific language is guided, firstly, by any explicit references the participants may make to how things are said or done in history, as these are valuable indicators of participants' perceptions. Furthermore, subject-specific terms and expressions and subject-specific discourse patterns and language functions are considered to be important indeces of language use typical of history. In addition, as an overarching frame, instances of subject-specific talk will in this study be approached as an interactional phenomenon rather than in isolation, with attention to how the participants jointly construct and negotiate their understanding of subject-specific use of language and/or ways of constructing knowledge. As Llinares and Morton (2010:47) argue, it is important to realize that subject-specific language and knowledge also involve interactional competence.

\section{Findings}

Before focusing on how the students talk about historical events during their peer discussions, a few words are in order about the group-work situations generally. The groups under observation here concentrate on their given tasks remarkably well, and there is very little off-record talk. In essence, then, almost everything they say during the group-work situations can be regarded as constructing their understanding of the topics they were given, the causes and consequences of the Industrial Revolution and of the American Civil War. However, as already stated above, attention will be focused on those instances of talk that seem to reflect their awareness of the subject of history requiring particular types of language use, indicated either by explicit reference to matters of terminology or by negotiations over relevant ways of constructing and/or displaying their knowledge of history.

\section{Explicit references to history}

Explicit references to history by the students are extremely rare during the peer discussions studied. In all the group sessions analysed, the word 'history' is only used ten times by the students. These few occurrences, however, reveal in an interesting way students' awareness of different subjects requiring specific types of talk. Furthermore, all the explicit references to history seem to relate to a certain type of policing of the group task by the students, because what seems to be the issue in both extracts, 1 
and 2, below is one of the participants wishing to stop what $\mathrm{s} /$ he perceives as either a distraction or a digression from history related talk, prompting the group to 'talk about' or 'concentrate on' history.

In Extract 1 Laura and Minna, who are working in their group with two boys, are discussing the Industrial Revolution when Minna feels distracted by Richard, a boy in another group who is talking in a loud voice about something unrelated to the task at hand. Minna makes the distraction explicit in line 7 , but when she receives no reaction from Richard, she catches his attention by calling his name in line 9 (none of the names in the transcripts are participants' real names). In lines 11-16 Minna demands that Richard stops what he is doing and concentrates on history because this is history lesson. Although the episode as a whole has probably more to do with playful teasing between teenage girls and boys than subject-specific language use, it suggests that Laura and Minna are oriented to subjectspecific talk and have a clear understanding of the kind of behaviour expected in history classrooms - no doubt a result of years of socialisation into classroom cultures.

\section{Extract 1 (Group 3)}

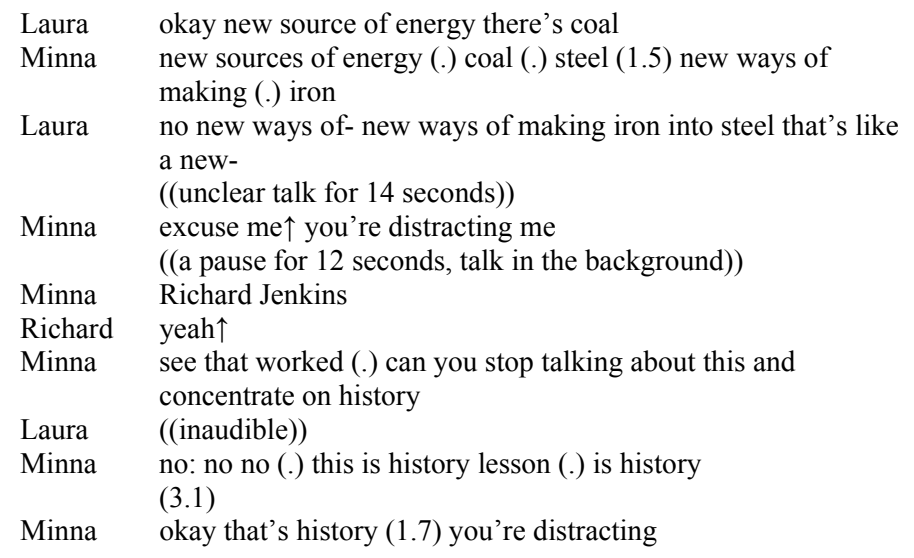

Extract 2 from the early stages of one group's work similarly shows awareness that school work involves shifts between everyday and subjectspecific language. Matti first seems to make a move from commenting on the recording equipment (lines 1-2) to talking about history (lines 4-7), with Ville taking up the suggestion (lines 9-10). However, when Matti, from line 12 onwards, starts using an artificial, high-pitched voice and seems to be

\footnotetext{
${ }^{2}$ See the Appendix for the transcription conventions.
} 
pretending to be assuming the role of the teacher when praising Ville's performance in the other group, it becomes obvious that he is play-acting and having fun - probably for the sake of the researchers, who he knows will later listen to the recordings. His skilful language performance shows his awareness of characteristics of the institutional talk of school and Ville's reactions (lines $16,30,33$ ) show that he is trying to stop Matti's roleplaying as it is out of line with what they have been instructed to do.

\section{Extract 2 (Group 1)}

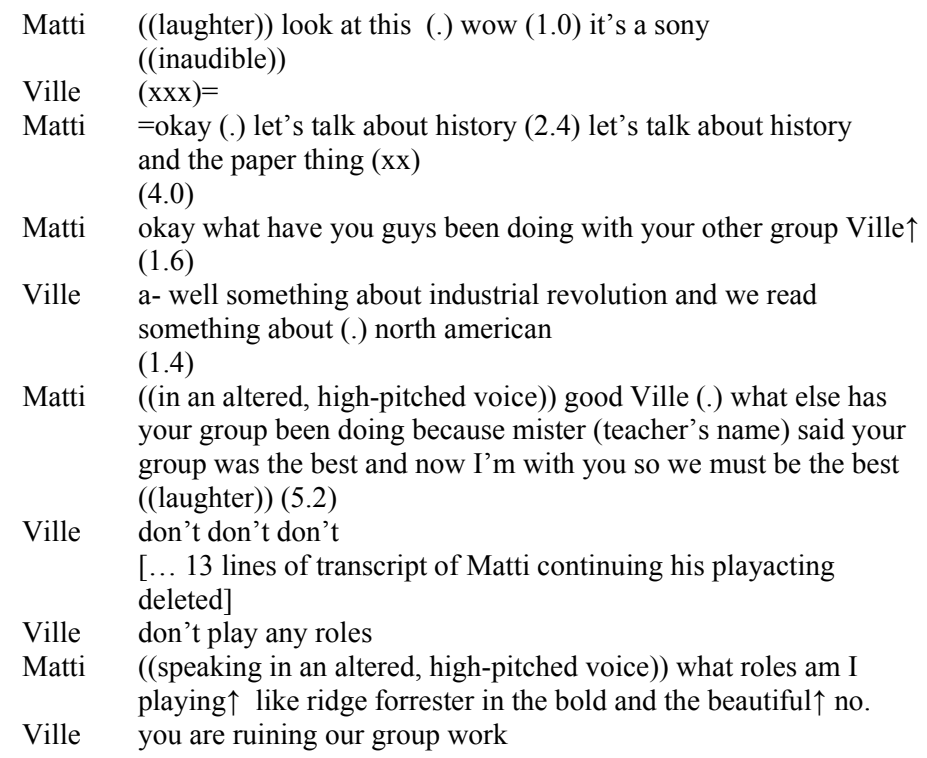

The extracts above serve to illustrate that when history is explicitly mentioned by the students, reference is usually being made to contextspecific behaviour in general - the need to keep to the task and topic of group talk and to talk about history - rather than to subject-specific language as such. However, as illustrated in the following sections, there are other ways in which the language of history is made salient.

\section{Awareness of subject-specific terms and concepts}

One of the groups has only two participants, Matti and Ville, two boys who seem to be at slightly different levels in terms of their fluency in English. In this group in particular there are several instances of the boys negotiating and coming to an agreement about terms and concepts. Some of the terms 
are more specific to history than others but in every case the question is about expressions that are more typical of formal, academic registers than of everyday spoken language. In other words, there is a clear sense in the extracts below of Ville in particular being aware of the existence of a subject-specific language repertoire that is rather formal in style, and of their need to work towards acquiring it. In other words, even though in CLIL classrooms the role of the teacher is often crucial in providing students with opportunities to come to an understanding of concepts, as shown for example by Alanen et al. (2008), in peer discussions a more knowledgeable classmate may also effectively support the process of advancing towards subjectspecific language use.

Extract 3 shows Ville and Matti discussing the American Civil War. Line 3 already gives a hint of Ville attuning to the formal register of the school subject when he repeats, laughingly, Matti's formulation more everything; the laughter indexes the expression as somehow problematic, in this case probably as too colloquial. In line 8 Ville more explicitly orients to appropriacy of expression when he recasts Matti's word people as population, a more technical and formal word. Matti acknowledges the recast by immediately repeating it (line 9) before continuing with his account. There is thus a sense of the boys, through joint meaning negotiation, gradually moving towards a more formal register of academic genres.

\section{Extract 3 (Group 1)}

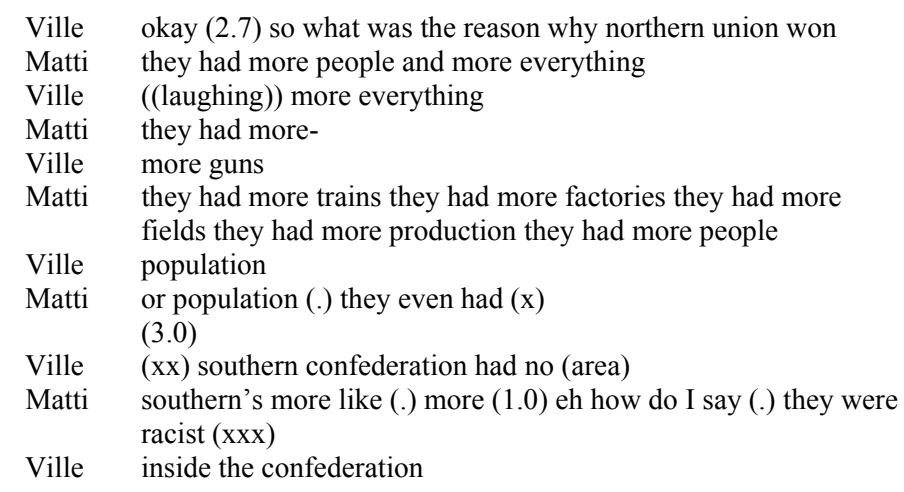

Another example of Matti and Ville negotiating over the meaning of a word concerns the word serf in Extract 4. Again, Ville is the more knowledgeable one and he is also clearly willing to assist Matti in meaning construction. That Matti is having some problems with the term is indicated by his 
apparent search for words in lines 1-2. Instead of reacting to Matti's problem, Ville at this stage initiates a joking exchange (lines 3-6). Matti's okay in line 8 signals the closure of joking and so a transition to more serious talk about the Industrial Revolution (lines 8-9). In this connection, he uses the word service, which Ville corrects to servants (lines 10-12) and a meaning negotiation, partly in Finnish, ensues (lines 12-18). Importantly, once agreement has been reached, interaction continues in English.

\section{Extract 4 (Group 1)}

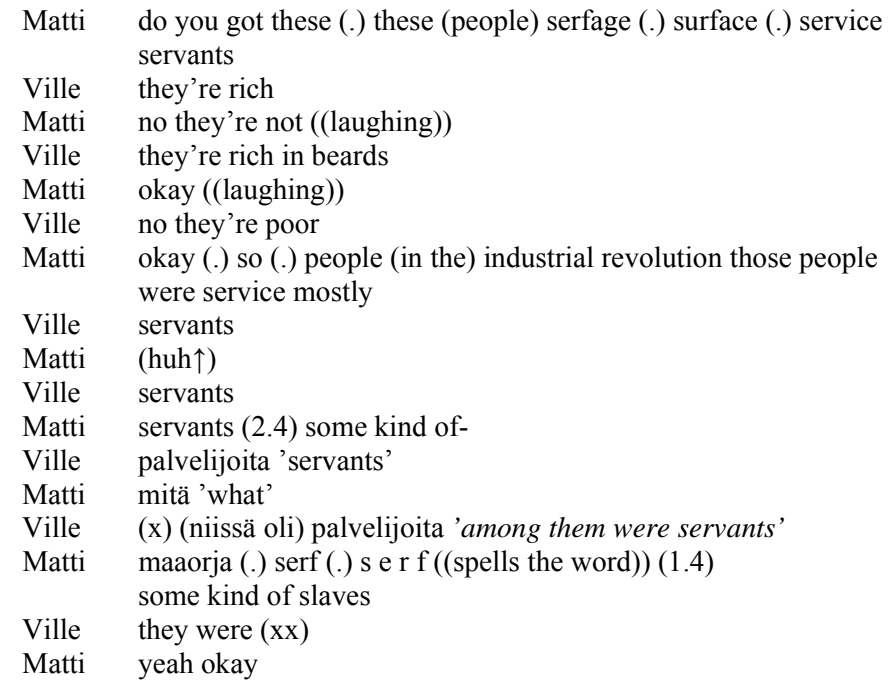

Finally, Extract 5 from another group shows Samuli and Richard discussing what they are expected to do during the group work. The extract also involves negotiating about terminology when the boys are searching for a shared understanding of what advent means in this context. The extract illustrates well the boys' awareness of the need to define the central concepts they are using (e.g. lines 4, 17-18), defining being very much a language function typical of academic genres. Furthermore, in lines 11-13 and 14-15 it is worth noting how the boys play with word pairs that include both a more everyday and a more academic version (things vs. events and coming vs. arrival). This seems to reflect their awareness of subject-specific language.

\section{Extract 5 (Group 3)}

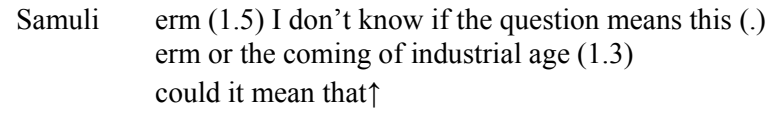




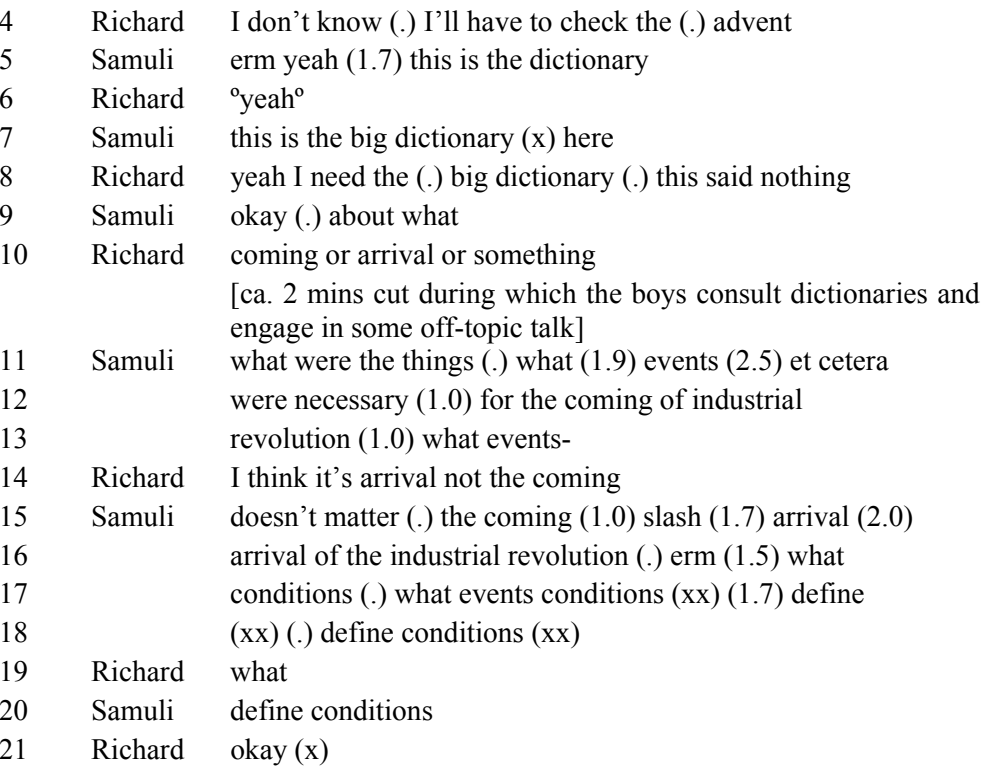

Two points thus seem to emerge as regards subject-specific terms and expressions. On the one hand, the students display some level of awareness of the need to move from everyday words to more abstract and academic expressions to capture the phenomena under discussion. On the other hand, the extracts also show that meaning negotiation is very much a shared, interactional undertaking among the participants.

\section{Use of subject-specific discourse patterns}

As Morton (2010: 86-67) points out, according to secondary level history curricula students are expected to gradually progress from 'recording genres' that retell events via 'explaining' genres that involve explanation and identification of cause and consequences to 'arguing' genres that require balancing different points of view of historical events. The $7^{\text {th }}$ graders in the present data are directed towards the explaining genre in that the teacher has specifically asked them to work through the causes and consequences of the two historical phenomena in question. In other words, they are expected to produce historical narratives and causal explanations and to forge connections between events, which are discourse patterns that are common in constructing knowledge in the school subject of history (e.g. Coffin 2006, Llinares \& Morton 2010). However, interestingly from the viewpoint of content and language integration, the teacher does not make any explicit 
references to whether the students might benefit from using some specific type of language to discuss these causes and consequences. It is therefore worth exploring what kind of resources students are able to use to forge causal connections in English.

Table1 provides an overview of the lexical means specifically geared to expressing cause-effect relationships during the group-work sessions. As the table shows, the students mostly tackle the task by creating a narrative of a sequence of events, linking propositions most often with conjunctions such as (and) then, or and. As regards expressing what the events lead to, the conjunction most often used is so, followed by because. The more academic vocabulary used to express cause-effect relationships such as nominalisations and verbs (e.g. 'consequence', 'effect', 'to result'), which Schleppengrell at al. (2004: 73, 84) refer to as typical ways of expressing cause-effect relations in history textbooks, are practically not used at all in the students' spoken language. The few occurrences of the nouns 'consequence', 'connection' and 'result' are all from a single occasion when a student refers to the written instructions given to the class by the teacher (we haven't read this yet, about conseq- (.) consequences (.) results (.) connections).

Table 1 Lexical elements used to express cause-effect relationships

\begin{tabular}{|c|c|}
\hline Conjunctions and nouns & $\begin{array}{c}\text { Number of } \\
\text { occurrences }\end{array}$ \\
\hline (and) then & 46 \\
and & 45 \\
so & 30 \\
because & 26 \\
that's why & 6 \\
therefore & 2 \\
consequence & 2 \\
connection & 1 \\
result & 1 \\
\hline
\end{tabular}

As pointed out above, the teacher has asked students to work through the causes and consequences of the two historical events in question; this may be considered an indirect way to lead them towards producing discourse typical of the school subject of history. Although the variety of linguistic means to express cause and effect relationships is rather small, the fact that students use them while engaged in shared meaning negotiations shows that they 
have at least some level of understanding of what kind of discourse they are expected to produce.

Extract 6 is an example of how students are engaged in producing subjectspecific discourse. It is from a situation in which two girls, Minna and Laura, are discussing the consequences of industrialisation for craftspeople. The extract illustrates, firstly, the use of so (lines 2, 4, 13, 14), and (lines 6, 17) and because (line 10) to connect different observations and to show relationships between them. Secondly, it shows that meaning making is a joint accomplishment, as Minna first brings in the fact of machines taking over in line 1, with Laura from line 2 onwards elaborating on the consequences this had for craftspeople. Minna first acts as a listener, providing supporting feedback (lines $3,5,8$ ), but soon also contributes to the historical narrative initiated by Laura (lines 10, 13, 17-19). The shared construction of the narrative shows the girls as agentive and responsible discourse participants, a state of affairs that may be more difficult to attain in whole-class situations where the social pressures related to speaking in public combined with the teacher's powerful role as the gatekeeper may hinder such active student participation.

\section{Extract 6 (Group 2)}

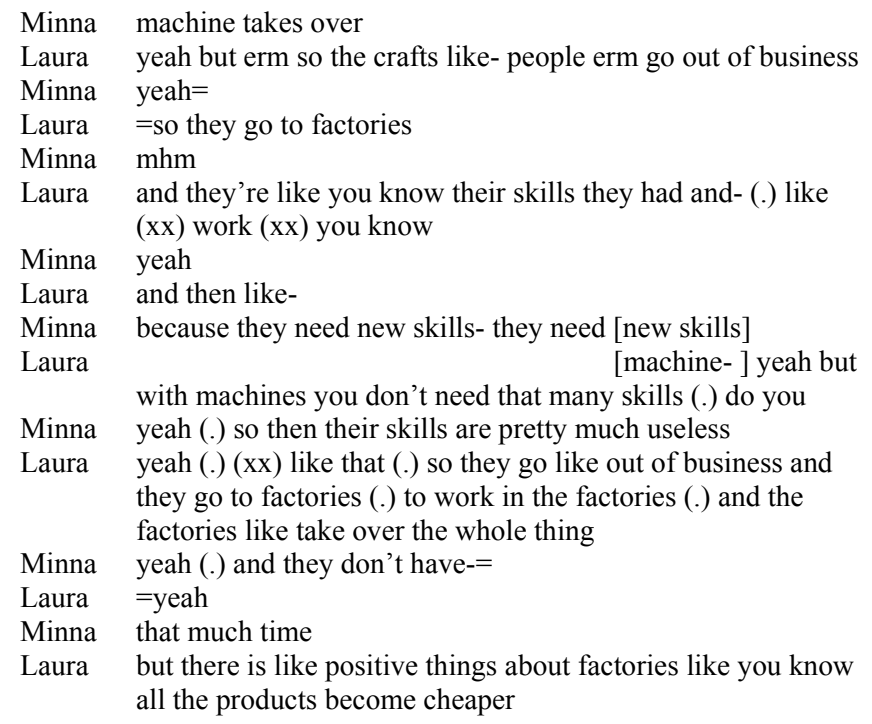

While the extract above showed students engaged in the discourse pattern of causal explanations, in Extract 7 the students are engaged in another type of 
discourse typical of history, that of drawing connections between different phenomena, in this case between increasing population and the Industrial Revolution. The extract is partly from the same group as above but it involves inter-group talk with Richard from Group 3 participating as well. Before this extract, Laura has tried to explain to her group how and why there is a connection between increasing population and the Industrial Revolution, talking about people from the countryside moving to towns because factories needed more workers. Her explanation is apparently not successful, judging from Minna's reaction: Laura's just trying to explain something to me that I don't $(x x)$. Laura pursues her efforts but when no mutual understanding seems to ensue, the girls turn to Richard, a member of another group, to check whether he understands the connection. Extract 7 begins with this appeal to Richard by Laura (lines 1-7). Minna's turns in lines 8 and 12 reveal that she doubts the connection between increasing population and the Industrial Revolution and regards them as two completely different things. Laura's reaction to this is to offer to explain the connection again to Richard (line 13), and she begins her explanation in line 19. Unfortunately the explanation itself could not be captured in the transcript because the poor quality of the recording combined with students' overlapping speech made deciphering impossible, but Minna's I understand it now a bit later suggests that they managed to reach a shared understanding. The extract shows the importance of the speech function of explaining (see Dalton-Puffer 2007:139-142) for history and also hints at the difficulties that CLIL students may encounter in realising this function in a foreign language. As Llinares and Morton (2010:49) point out, CLIL students do not necessarily have much experience of using language to express causality.

\section{Extract 7 (Group 2)}

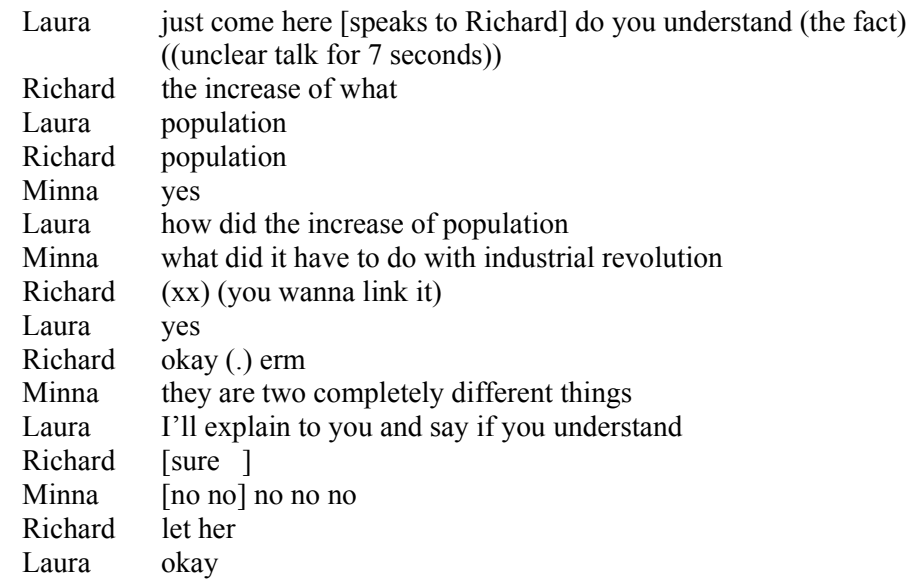




\begin{tabular}{|c|c|}
\hline Minna & it's gonna take a while \\
\hline Laura & (okay when there's) more people there's more people trying to \\
\hline 20 & get the job and erm bosses $(\mathrm{xx})$ trying to make $(\mathrm{xxx})(1.0)(\mathrm{xx})$ \\
\hline 21 & $\begin{array}{l}\text { more people more workers [continues explanation which is } \\
\text { uninterpretable due to overlapping speech ]] }\end{array}$ \\
\hline
\end{tabular}

Extract 8 serves as the final example of the students' apparent awareness of what kind of discourse and language functions are required from them to complete the group work. The extract comes from a point at which Matti and Ville have discussed the causes and consequences of the American Civil War and are now in the process of wrapping up the discussion and attempting to produce a concise account, with Ville describing the essence of the war and Matti supporting him in this. In line 3, Ville explicitly states that's the nutshell to characterize the function of his talk. It has been clear throughout this pair's work that Ville is better positioned to take charge of the situation, both linguistically and because he seems to have prepared for the lesson better. Interestingly, towards the end of the extract (lines 11-12) Ville resorts to ironic self-appraisal, as if to mockingly play down his knowledgeability for reasons of solidarity. This seems to be well received by Matti, who joins the fun by roleplaying (line 13); shared laughter closes off the situation.

\section{Extract 8 (Group 1)}

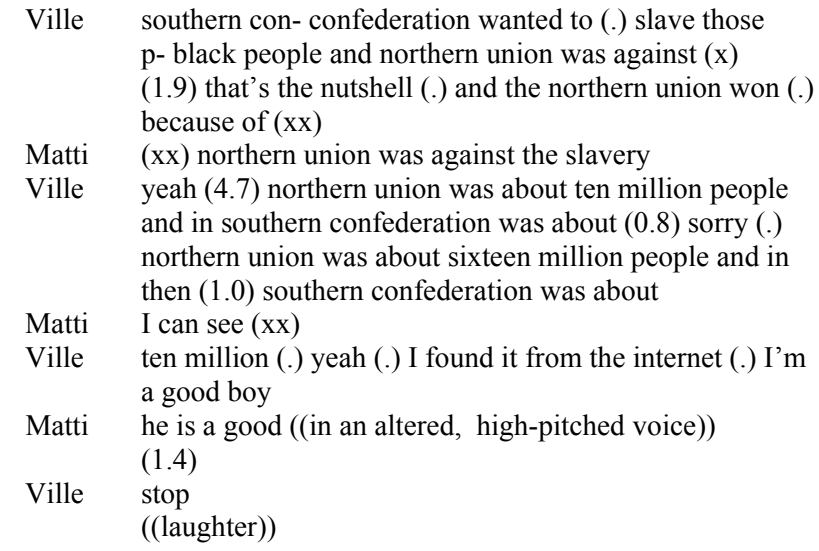

What the extracts above have highlighted is that the students are actively using English during their group-work sessions to construct a shared understanding of the tasks at hand and the historical phenomena involved. More importantly from the viewpoint of the focus of the present chapter, they employ discipline and subject-relevant language in their peer 
discussions. No doubt the teacher's instruction to focus on causes and consequences has had an important role in steering the students' work and language use. The following extract from a situation where the teacher briefly discusses the subject with one of the groups shows, moreover, how the teacher motivates the learners to search for links between the causes and consequences:

$\mathrm{T}$ this is just that you (x) are learning history in a patchwork quilt (.) type way so you learn all these details but it's difficult to step back and see how yeah you'll see all that happens on the quilt but you gotta step away from the quilt and see how the quilt is all made which is very difficult but if you get practice in that (.) all the details should start making sense in the grander design (.) the bigger picture (.) so it'd be easy for me to ask you for example what different inventions (x) industrial revolution (1.0) and I could ask you something about the social effects (.) but I'm hoping you can start understanding how all these things are related (.) manufacturing textiles (.) industrialization (.) social effects (.) these inventions how they all work together all these details

Such meta-level descriptions are important in steering students' attention to how things are done and how understanding is achieved in specific subjects. However, from the viewpoint of content and language integration and awareness of subject-specific language use in CLIL, the next step could be to explicitly draw students' attention to language functions that are involved in presenting knowledge in subject-specific ways.

\section{Concluding remarks}

According to Llinares and Morton (2010:47), CLIL is about developing L2 academic literacies, and "[p]articipating in CLIL lessons entails using spoken language to carry out a range of academic language functions through which relevant subject-related meanings are expressed". The purpose of this chapter has been to explore Finnish secondary-level CLIL history students' language use in group-work situations from the perspective of subject-specific language use, an essential yet relatively underexplored aspect of CLIL education.

Even though the data sample is limited and obviously cannot be used for making broad generalisations, some observations can be made that are worth taking further. Firstly, the present data seem to show that subject-specific language use is very rarely explicitly discussed. Admittedly, there are some references to the need to 'talk about history' during the group-work sessions 
but they seem to relate to the topics of talk rather than their linguistic and/or discoursal realisation. Nevertheless, through their language use when carrying out group work and pair work, the students display at least some level of awareness that history requires a particular type of language use. Above, this was shown to be realized on two levels. Firstly, during their group work the students were engaged in meaning negotiations over terms, showing in this process some sensitivity to the difference between everyday and academic language use. Noteworthy in this process was how the students strove towards a shared understanding and joint meaning-making through very involved interaction in ways that are often absent in whole-class situations, which reminds one of Moore's (2011) observation that CLIL students' participatory patterns are more often collaborative than those of their mainstream peers.

Secondly, and even more significantly from the perspective of subjectspecific language use, the students were shown to be actively engaged in discourse patterns typical of history: providing explanations, seeking causal connections, attempting syntheses through providing 'the big picture' and teasing out the essence from the multitude of factors involved through identifying what the teacher had referred to as 'the nutshell'. They were clearly aware of what they were expected to do in their group work. However, it is unclear to what extent they associate these activities with specific academic speech functions and particular ways of using language.

As regards the role of peer discussions in supporting the learning of subjectspecific language use, the findings of this study seem encouraging. Groupwork situations in CLIL lessons are often suspected of both discouraging the use of the target language and encouraging off-topic talk. In the present data, the students use English throughout and keep to the tasks and topics at hand very well. It may well be that this can largely be explained by their awareness of being recorded for research purposes. Yet the data undeniably show that 13-year-old students are fully able to negotiate their way through group-work tasks in English and to engage in complex and purposeful meaning negotiations around historical events and concepts. It is hence likely, as Llinares and Morton (2010:62) argue, that "CLIL students may be able to do more than we think, if we provide them with the interactional space to articulate their understandings". It seems that group work among peers forms a safe environment, provided that students have a clear understanding of what activities they are expected to perform.

Mondada and Pekarek Doehler (2004:515), when studying task accomplishment in second language classrooms, argue that it "necessarily 
involves various embedded linguistic, interactional, institutional competences". Judging from the present data, joint meaning construction in group-work situations also involves a complex range of competences, and it seems that one fruitful avenue for future CLIL research would be a more comprehensive account of content and language integration than has been achieved to date as a phenomenon relating not only to language and content but also to (subject-specific) patterns of discourse and the choreography of interaction involved when participants are striving towards shared understandings. Gajo (2007:564) is thinking along similar lines when he argues that integration is "a complex interactional and discursive process relevant to both the language(s) and the subject". This study, although small in scale, has hopefully provided some insights into the complexities involved and into both explicit and implicit ways in which students' peer discussions index their awareness of subject-specific language use.

\section{References}

Alanen, R., A.-K. Jäppinen and T. Nikula (2008) "But big is a funny word": A multiple perspective on concept formation in a foreign-language-mediated classroom, Journal of Applied Linguistics 3(1)/2006: 69-90.

Christie, F. (2002) Classroom Discourse Analysis. A Functional Perspective. London: Continuum.

Coetzee-Lachmann, D. (2007) Assessment of subject-specific task performance of bilingual geography learners: Analysing aspects of subjectspecific written discourse. PhD Dissertation, Universität Osnabrück. http://repositorium.uni-osnabrueck.de/bitstream/urn:nbn:de:gbv:7002009030617/2/E-Diss864_thesis.pdf

Coffin, C. (2006) Learning the language of school history: the role of linguistics in mapping the writing demands of the secondary school curriculum, Journal of Curriculum Studies 38(4): 413-429.

Coyle, D. (2007) Content and language integrated learning: Toward a connected research agenda for CLIL pedagogies, The International Journal of Bilingual Education and Bilingualism 10: 543-562.

Coyle, D., P. Hood and D Marsh (2010) CLIL. Content and Language Integrated Learning. Cambridge: CUP.

Creese, A. and P. Martin (2003) Multilingual Classroom Ecologies: InterRelationships, Interactions and Ideologies. Clevedon: Multilingual Matters. 
Dalton-Puffer, C. (2007) Discourse in Content and Language Integrated Learning (CLIL) Classrooms. Amsterdam: John Benjamins.

Dalton-Puffer, C. and U. Smit (eds.) (2007) Empirical Perspectives on CLIL Classroom Discourse. Frankfurt: Peter Lang.

Dalton-Puffer, C. T. Nikula and U. Smit (eds.) (2010a) Language Use and Language Learning in CLIL Classrooms. Amsterdam: John Benjamins.

Dalton-Puffer, C., T. Nikula and U. Smit (2010b) Charting policies, premises and research on content and language integrated learning. In Dalton-Puffer, C., T. Nikula and U. Smit (eds.) 2010a, 1-19.

Dalton-Puffer, C., T. Nikula and U. Smit (2010c) Language use and language learning in CLIL: Current findings and contentious issues. In Dalton-Puffer, C., T. Nikula and U. Smit (eds.) 2010a, 279-291.

Fortune, T. W. and D. J. Tedick (eds.) (2008) Pathways to Multilingualism: Evolving Perspectives on Immersion Education. Clevedon: Multilingual Matters.

Gajo, L. (2007) Linguistic knowledge and subject knowledge: How does bilingualism contribute to subject development? The International Journal of Bilingual Education and Bilingualism 10(5): 563-579.

García, O. (2009) Bilingual Education in the 21st Century: A Global Perspective. Malden, MA and Oxford: Wiley-Blackwell.

Järvinen, H.-M. (2010) Language as a meaning making resource in learning and teaching content. Analysing historical writing in content and language integrated learning. In Dalton-Puffer, C., T. Nikula and U. Smit (eds.) 2010a, 145-168.

Lantolf, J. P. and M. E. Poehner (eds.) (2008) Sociocultural Theory and the Teaching of Second Languages. London: Equinox Publishing.

Lemke, J. (1990) Talking Science: Language, Learning, and Values. Norwood, NJ: Ablex.

Leung, C. (2005) Language and content in bilingual education, Linguistics and Education 16: 28-252.

Lim Falk, M. (2008) Svenska i engelskspråkig skolmiljö. Ämnesrelaterat språkbruk i två gymnasieklasser. (Swedish in an English-language School Environment. Subject-based Language use in two upper secondary classes.) Acta Universitatis Stockholmiensis. Stockholm Studies in Scandinavian Philology. 
Llinares, A. and T. Morton (2010) Historical explanations as situated practice in content and language integrated learning, Classroom Discourse 1(1): 46-65.

Llinares, A. and R. Whittaker (2010) Writing and speaking in the history class. A comparative analysis of CLIL and first language contexts. In Dalton-Puffer, C., T. Nikula and U. Smit (eds.) 2010a, 125-143.

Mondada, L. and S. Pekarek Doehler (2004) Second language acquisition as situated practice: Task accomplishment in the French second language classroom, The Modern Language Journal 88: 501-518.

Moore, P. (2011) Collaborative interaction in turn-taking: a comparative study of European bilingual (CLIL) and mainstream (MS) foreign language learners in early secondary education, International Journal of Bilingual Education and Bilingualism 14 (5): 531-549.

Mortimer, E. F. and P. H. Scott (2003) Meaning Making in Secondary Science Classrooms. Maidenhead, UK: Open University Press.

Morton, T. (2010) Using a genre-based approach to integrating content and language in CLIL. In Dalton-Puffer, C., T. Nikula and U. Smit (eds.) 2010a, 81-104.

Nikula, T. (2005) English as an object and tool of study: interactional effects and pragmatic implications, Linguistics and Education 16 (1): 27-58.

Nikula, T. (2008) Learning pragmatics in content-based classrooms. In E. Alcón and A. Martinez-Flor (eds.) Investigating Pragmatics in Foreign Language Learning, Teaching, and Testing. Clevedon: Multilingual Matters, 94-113.

Nikula, T. (2010) On teachers' interactional resources to make subjectspecifc language use salient in CLIL. A paper presented in AILA CLIL Network Research Symposium, University of Jyväskylä, June 10-11 2010, University of Jyväskylä.

Ruiz de Zarobe, Y. and R. M. Jiménez Catalán (eds.) (2009) Content and Language Integrated Learning. Evidence from Research in Europe. Bristol: Multilingual Matters.

Schleppegrell, M. (2004) The Language of Schooling. A Functional Linguistics Perspective. Mahwah, NJ: Lawrence Erlbaum.

Schleppegrell, M., M. Achugar and T. Oteíza (2004) The grammar of history: Enhancing content-based instruction through a functional focus on language, TESOL Quarterly 38 (1): 67-93. 


\section{APPENDIX}

\section{TRANSCRIPTION CONVENTIONS}

\begin{tabular}{|l|l|}
\hline $\begin{array}{r}\text { overlapping [speech] } \\
\text { [text ] }\end{array}$ & overlapping speech \\
\hline$()$. & a short pause that is not timed, less than a second \\
\hline$(2.5)$ & a pause, timed in seconds \\
\hline $\begin{array}{l}\text { text }= \\
\text { text }\end{array}$ & latching utterances \\
\hline exte:nsion & noticeable extension of the sound or syllable \\
\hline cut off wo- & cut off word or truncated speech \\
\hline${ }^{\text {'high circles }}{ }^{\circ}$ & $\begin{array}{l}\text { spoken more silently than surrounding } \\
\text { utterances }\end{array}$ \\
\hline. & falling intonation \\
\hline$\uparrow$ & rising intonation \\
\hline$(($ text)) & transcriber's comments \\
\hline$($ text $)$ & transcriber's interpretation of unclear word(s) \\
\hline$(\mathrm{x})$ & unclear speech, probably a word \\
\hline$(\mathrm{xx})$ & unclear speech, probably a phrase \\
\hline$(\mathrm{xxx})$ & longer stretch of unclear speech \\
\hline & \\
\hline
\end{tabular}

